\title{
Community Preferences Determine Shape and Appearance of Residential Buildings in Compliance with Perwali No 25 Year 2010 in Denpasar Selatan
}

\author{
Kadek Wigunantara Eka Putra ${ }^{1}$, Antonius Karel Muktiwibowo², I Gusti Ngurah Anom Rajendra ${ }^{3}$ \\ Magister Architecture \\ Faculty of Engineering, Udayana University \\ Denpasar, Bali \\ wigunantara@gmail.com \\ Architecture Department \\ Faculty of Engineering, Udayana University \\ Denpasar, Bali \\ Architecture Department \\ Faculty of Engineering, Udayana University \\ Denpasar, Bali
}

\begin{abstract}
This study aims to determine the level of community compliance in South Denpasar and differences in people's preferences in complying with Mayor Regulation No. 25/2010. The research method used in this research is descriptive quantitative method with a survey approach. The number of respondents in the study were 100 people who were selected using multy stage sampling. The analysis technique used is the Frequency Distribution Analysis Technique (New Rank) and the Analytical Hierarchy Process (AHP). While the validity test was carried out by using the Product Moment Correlation Technique and the reliability test with Cronbach's Alpha. Public preferences in complying with Mayor Regulation No. 25/2010 vary widely, because each community group has different desires with their respective priority values for research aspects, as well as the level of compliance obtained from field findings. Communities with higher income have a higher level of compliance than others, but do not have a good scale of attitude towards compliance with applicable regulations, and vice versa.
\end{abstract}

Index Terms - preference, compliance, regulation.

\section{INTRODUCTION}

A house as a private area is an area that is owned and controlled by the owner (community) and is designed and built with the preference of the community as the decision holder for the rights to their own land. So that the needs, functions, form and appearance will differ from one another[1]. Meanwhile, on the other hand, the Unitary State of the Republic of Indonesia is a constitutional state, where everything and everything related therein must be subject to and obey the applicable law. As regulated by the Mayor's Regulation Number 25 of 2010, which discusses the principles of spatial planning and orientation, the principles of building layout, and the principles of decorative patterns that affect the shape and appearance of public houses in Denpasar City. Judging from the description, it is very necessary to take this case into research material to prove the individual preferences of the community in determining the shape and appearance of the building in obeying Perwali No. 25 of 2010. In this study, researchers tried to take approaches that pay attention to interactions involving human decisions themselves, the desires of humans themselves and the level of compliance by exploring community preference factors determining the shape and appearance of residential buildings in complying with Mayor Regulation Number 25. The year 2010.

\section{METHOD}

The research method used is descriptive quantitative. This research method is a method that aims to identify a particular symptom, or to get new ideas from that symptom in order to formulate a problem in detail. This research 
method is used because through this approach it is hoped that a deeper study and description of the object under study will be obtained. Researchers will compile a research instrument that is used as a data collection tool in the form of a questionnaire, to guide interviews or observations[2].

The research design includes determining the research location, determining research variables, determining the types and sources of data, making research instruments, determining data collection techniques, and determining data analysis techniques. The research begins with a review of various literature in the form of books, existing research in the form of theses and journals, especially those related to the preparation of literature reviews, supporting theories and cases of empirical research that have relevance to what will be studied for the method used. The data obtained from questionnaires were then tabulated and analyzed to determine people's preferences in determining the shape and appearance of residential buildings in compliance with Mayor Regulation Number 25 of 2010 in South Denpasar. Then conclusions will be drawn to answer the formulation of the research problem. In this study, the researcher determined the variable from the specified title, the operational definition of the research variable will be presented in table 1.

TABLE I

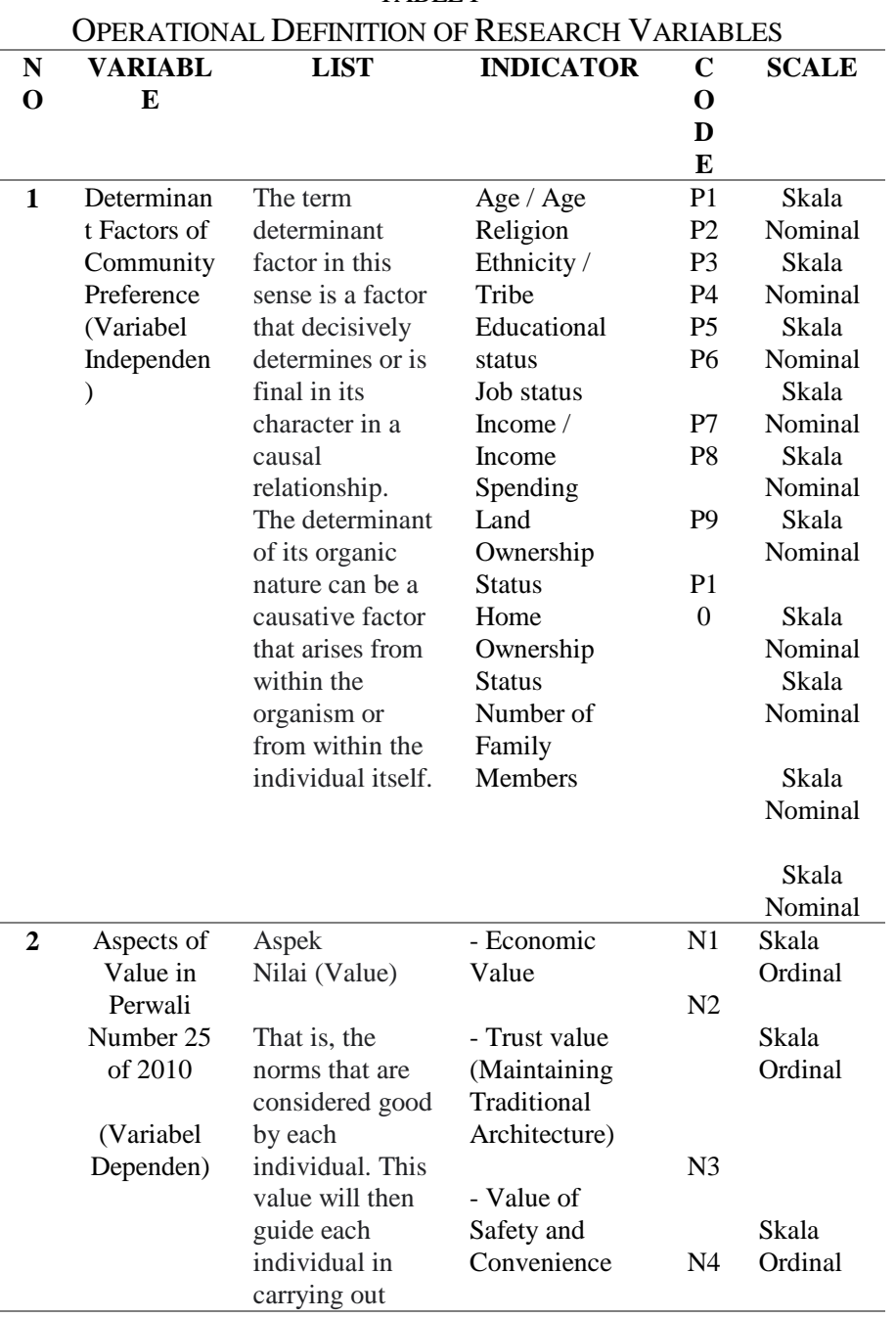

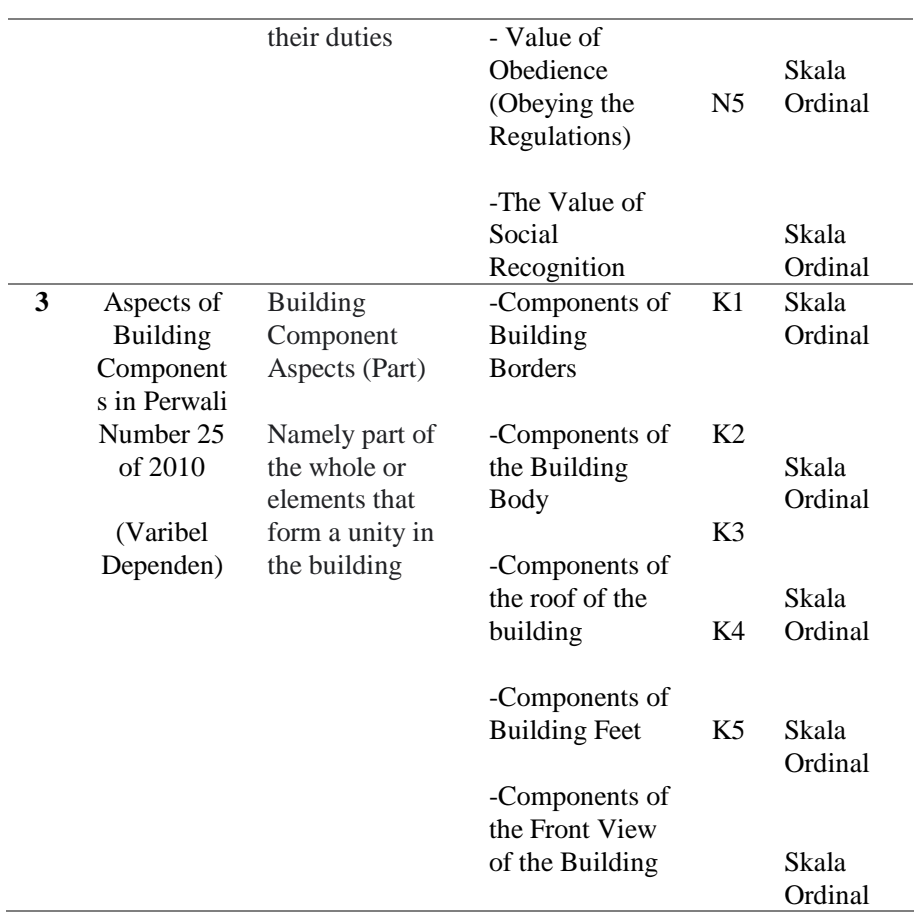

The sampling method used was multi-stage sampling which was divided into smaller sub-units. This method is used because the research area is wide [3]. Samples were taken from all districts of South Denpasar including Sidakarya Village, Pemogan Village, Sanur Kauh Village, Sanur Kaja Village, Panjer Village, Renon Village, Sanur Village, Sesetan Village, Pedungan Village, Serangan Village. The population referred to in this study is the number of owners of residential buildings with standing or established status above 2010 (after Mayor Regulation Number 25 of 2010 was issued).

In each village and kelurahan, an environment and corridor will be selected using a random system. The number of samples is then divided based on low income, middle income, and high income groups. In each village and kelurahan, a minimum of 10 samples will be selected. These ten samples consist of a minimum of $3(30 \%)$ low-income people, a minimum of $4(40 \%)$ middle-income people and a minimum of $3(30 \%)$ high-income people in every village and sub-district in South Denpasar. To find out the sample of high, middle and low income, the researcher asked the community directly about their opinion or saw physically the condition of the house they currently occupy. The community groups in this study are classified based on income in accordance with the theory of consumer choice, where the theory states preferences with consumption expenditures explaining how market price and income conditions impact consumption patterns and choices for consumer goods and services. Consumer choice theory is a microeconomic theory that connects the consumer demand curve with consumer preferences. The theory seeks to understand the source of consumer demand through consumer theory. This theory views that consumers fully understand what they choose[4]. 
The analysis used is an attitude scale measuring instrument with a frequency distribution formula (new rank) and analytical hierarchy process (AHP) which is carried out only looking for a generally prioritized order of the variables studied for each paired matrix, without looking for the cause of the choice being a priority. This is due to the limited research time with a number of complex variables. In investigating social perceptual processes, studying humans, concept formation, personality development and attitude formation it is better to use the attitude scale measurement to see the influence on human behavior. The attitude of building the number one important component in the human psyche that influences the decision of something to choose [5]. The things that respondents consider in complying with Mayor Regulation Number 25 of 2010 can be described according to research data using a Frequency Distribution attitude scale [6] below this :

Very Insignificant (STP): Has a value of 1

Not Important (TP): Has a value of 2

Ordinary (B): Has a value of 3

Important (P): Has a value of 4

Very Important (SP): Has a value of 5

The data is then processed by providing a value for each answer to provide a total value. After having a value then re-ranking it so that the order is obtained using the frequency distribution formula:

$\mathrm{Pk}=\mathrm{Nb}-\mathrm{Nk}$

$\mathrm{Ki}$

The Analytical Hierarchy Process (AHP) method is a decision-making method designed to solve unstructured problems and the criteria are many and difficult to quantify. Basically the Analytical Hierarchy Process (AHP) method breaks down a situation or problem that is complex, unstructured, into its component parts, arranging parts or variables into a hierarchical arrangement, giving numeric values to subjective considerations of the relative importance of each variable, and synthesizing these various considerations to determine which variable has the highest priority and acts to influence the outcome in that situation [7]. The Analytical Hierarchy Process (AHP) method was developed by Thomas L. Saaty, a mathematician from the University of Pittsburgh in the United States in the 1970s while at the Wharton School (University of Pennsylvania). The Analytical Hierarchy Process (AHP) method, logical factors, intuition, experience, knowledge (data), emotions and feelings are tried to be integrated and optimized through a systematic and measured process. Scale measures of various criteria or importance that are difficult to quantify and compare and replace with a more flexible scale called priority. This priority is an abstract measure that applies to all scales. The Analytical Hierarchy Process (AHP) method has the following basic principles: hierarchical arrangement, priority setting and logical consistency testing. The advantage of the Analytical Hierarchy Process (AHP) method is that if one is faced with a complex or framed situation, there is little or no statistical data and information on the problem faced. In other words, the problems faced can be felt and seen, but the completeness of numerical data in the form of statistical numbers does not support researchers to model quantitatively. The steps used in the Analytical Hierarchy Process (AHP) method are; Defining the problem and setting goals. Organizing the problem into a hierarchical structure, the desired goal of the problem is placed at the highest level in the hierarchy. The next level is the translation of these objectives into more detailed sections. This description is carried out continuously up to the operational level.

The results of data collection that have been analyzed will be presented informally in the form of tables, graphs and pictures, then described in words / narratives that are able to provide a systematic explanation. Conclusions are drawn based on careful and in-depth analysis of the data obtained.

The results of data collection that have been analyzed will be presented informally in the form of tables, graphs and pictures, then described in words / narratives that are able to provide a systematic explanation. Conclusions are drawn based on careful and in-depth analysis of the data obtained. The presentation of the analysis results based on the data is presented in table 2 .

TABLE II

VALIDITY TEST RESULTS

\begin{tabular}{ll}
\hline \multicolumn{1}{c}{ Data } & $\begin{array}{c}\text { Methods and Techniques for } \\
\text { Presentation of Data } \\
\text { Analysis Results }\end{array}$ \\
\hline Karacteristic Respondent & Figure, Table, Narrative \\
\hline Data Analisis & Table and Narrative \\
\hline $\begin{array}{l}\text { Analytical } \\
\text { (AHP) }\end{array}$ & Hierarchy \\
\hline
\end{tabular}

\section{PREFERENCE}

According to the Big Indonesian dictionary preferences are choices, likes, tendencies or things that take precedence, priority and priority over others. Preference comes from English "preference", namely something prefered, one's first choice, greater liking, giving of priority advantage to something, [8], which means that something that is more desirable, a first choice, is a priority need and gives better profit. Preference is something that must take precedence, and take precedence over others, priorities, choices, trends and preferences [9]. Preference is evaluative in assessing the surrounding environment so that it can influence decision making while perception is an experience to feel the surrounding environment.

Preference is an individual desire or tendency to choose and have something [10]. Housing preference can also be interpreted as a desire to choose and have a housing attribute condition with the occupant as a decision maker so that it contains the meaning of an occupant's process of realizing the desired condition of the house. Preference relates to behavior, perceptions, responses and responses in making decisions or some alternative choices. Individual 
perceptions in the environmental context are differentiated into environmental perception or preference, environmental cognition and environmental perception [11].

Preference is based on the background of different levels of needs and interests that are influenced by information derived from perceptions and interactions of people with other communities. Community housing preferences relate to the priority scale of the community towards housing where low-income people are more concerned with the priority scale of housing locations close to the place of work rather than land ownership status and housing quality [12]. Preference relates to the cognitive processes involved in forming mental representations of and experiences about the environment, between cultures in environmental experiences, which are related to images. To make it easier to find one's preferences, an extensive series of experiments were carried out using a variety of sample scenes for preference assessment analysis to identify groups of samples found and develop an information processing preference model [13]. This is supported by research [14], which states that the appearance of images and scenes / videos will make it easier to find one's preferences, so that the type, quality and environmental group can be seen.

Preferences are human wants / choices that have varied characteristics that are the main source of patterns and trends in urban and regional populations. The role of preference in population distribution is a complex phenomenon. A movement will occur if the benefit value exceeds the price value [15]. The level of provision and comfort of adequate public goods facilities greatly affects the level of public preference in choosing a housing location.

\section{A. Level of Public Compliance with Regulations}

According to [14] in his book The Social Order, the process of one's obedience to the law may occur due to several factors, namely Indoctrination (intentionally planting of obedience), namely that a legal rule becomes a doctrine that is intentionally planted in society. This is done so that the application of the law is evenly distributed throughout all levels of society, so that the desired legal compliance can be realized. Habituation (habituation of behavior), namely someone will obey the rules of the law because of the routine they do. Like someone who routinely wears a helmet when riding a motorcycle. Utility (utilization of obeyed rules), namely someone obeying the legal regulations because they can take advantage of the rules substantially. Group Identification (identifying in a certain group), that is, someone will obey the law when seeing or referring to a group that has implemented it.

However, it should also be noted that even though a norm has been socialized in such a way and has been institutionalized, it is not certain that the norms have truly been internalized in each member of the community.

In this connection, according to Ernst Utrecht [15] in his book Introduction to State Administrative Law, there are several things that cause a person to obey the law, namely; One feels that the rules are perceived as law. This means that they really have an interest in the enactment of this rule or law. Someone does have to accept it so that there is a sense of peace. This means that people choose to obey the law so that they do not have many difficulties in their life. Someone or society really wants it, because in general, people only feel the existence of law if the extent of their interests is limited by existing legal regulations. Someone obeys the law because of social coercion (sanctions). . People generally feel ashamed or worried about being accused of being an associate if people break the law.

\section{B. Shape and Building Form}

Shape is a meeting point between space and mass. Shape is also a geometric description of the part of the universe of the plane that is occupied by the object, which is determined by its outer boundaries but does not depend on its location (coordinates) and orientation (rotation) to the plane of the universe that is occupied. In architecture, form is the important thing. Form is the output or final output that can be seen by building users

According to Vitruvius, there is no such thing as form. Form, for Vitruvius, if you want to be associated with function / utility, of course, it is a combination of firmistas (technic) and venustas (beauty / delight) [16]. The form / form is the result of a certain configuration of the surfaces and the sides of the shape [3]. Architectural form is the meeting point between mass and space. Architectural forms, textures, materials, the separation between light and shadow, color, are a combination in determining the quality or soul in the depiction of space. The quality of architecture will be determined by a designer's expertise in using and unifying these elements, both in the formation of the interior (interior) and the outer (exterior) spaces around the buildings [4]. Form is an inclusive term which has several meanings. Shape can be attributed to an external, recognizable appearance such as a chair or a person sitting on it. It also describes certain conditions under which something can manifest its existence, for example when we talk about water in the form of ice or steam. In art and design, the term is often used to describe the formal structure of a work - the ways of arranging and coordinating the elements and parts of a composition to produce a real picture.

Architectural appearance can be ascertained as the presence of architecture as a real object, which is immediately captured by the sense of sight. The face or appearance of architecture can be presented as a synonym for appearance. [17] This appearance is the result of space and function work. The appearance tells, in visual language, the designation or use of the architecture, and it is therefore less commendable that it looks like a typical house but its use is for the office. The appearance tells the present of the time or era or the design or construction period of the architecture. The display tells you the status, prestige, 
lifestyle and dreams of the owner. The display tells you the architectural style or style to be used. Displays indicate geographic or ethnic orientation such as global, local. The look touches the taste and the sense that makes a certain impression Views are advertisements that attempt to attract potential buyers. Artistic or aesthetic compositions, compositions that foster charm in the audience. Appearance is the carrier of the architect's architectural features.

\section{DATA AND ANALYSIS}

\section{A. Validity Test Results}

Based on the calculated value in the validity test with a measuring device by comparing the $r$ table value of 0.1 by entering the questions. The validity test was carried out using the product moment correlation technique formula. The results of the validity test can be seen in table 3 .

TABLE III

\begin{tabular}{|c|c|c|c|c|}
\hline \multicolumn{5}{|c|}{ VALIDITY TEST RESUltS } \\
\hline No & Indicator & r_Count & r_Table & Info \\
\hline \multirow[t]{6}{*}{1} & Valuable Aspect & & & \\
\hline & Economic & 0,993 & 0,1 & Valid \\
\hline & Architecture & 0,840 & 0,1 & Valid \\
\hline & Safety & 0,264 & 0,1 & Valid \\
\hline & Obedience & 0,526 & 0,1 & Valid \\
\hline & Social Aspect & 0,666 & 0,1 & Valid \\
\hline \multirow[t]{6}{*}{2} & Building Aspect & & & \\
\hline & $\begin{array}{l}\text { Building Boundary } \\
\text { Line Components }\end{array}$ & 0,931 & 0,1 & Valid \\
\hline & Building Shape & 0,957 & 0,1 & Valid \\
\hline & Building roof & 0,448 & 0,1 & Valid \\
\hline & Building Fondation & 0,770 & 0,1 & Valid \\
\hline & Facade & 0,991 & 0,1 & Valid \\
\hline
\end{tabular}

\section{B. Reliability Test Results}

The reliability test results obtained in this study all have reliable candidates. This is indicated by the large enough Cronbach's Alpha coefficient value for each variable, so that it can be used in the analysis of this study. Reliability test results can be seen in table 4 .

TABLE IV

RELIABILITY TEST RESULTS

\begin{tabular}{clccc}
\hline No & indicator & $\begin{array}{c}\text { Cronbach's } \\
\text { Alpha }\end{array}$ & Information & Koefisien \\
\hline $\mathbf{1}$ & Value & 0,615 & Reliabel & Koef. Tinggi \\
\hline $\mathbf{2}$ & $\begin{array}{l}\text { Component } \\
\text { aspect }\end{array}$ & 0,887 & Reliabel & $\begin{array}{c}\text { Koef. Sangat } \\
\text { Tinggi }\end{array}$ \\
\hline
\end{tabular}

\section{Compliance Level Conditions}

To find out the condition of the level of community compliance in South Denpasar regarding the shape and appearance of residential buildings, the researcher presented in the form of a percentage table of compliance with a total of 100 respondents, next will be divided based on community income with 3 categories that have been determined in the sampling method.

\begin{tabular}{|c|c|c|c|c|}
\hline \multicolumn{5}{|c|}{ COMPLIANCE LEVEL CONDITIONS } \\
\hline $\begin{array}{l}\text { N } \\
\text { o. }\end{array}$ & Regulation Aspect & valid & $\begin{array}{l}\text { Not } \\
\text { valid }\end{array}$ & Info \\
\hline A & Regulation Line & & & with IMB : \\
\hline 1 & Building Line (GSB) & 57 & 43 & \\
\hline 2 & Near frontier (GSS) & 17 & 83 & Responden \\
\hline 3 & Back frontier (GSBB) & 35 & 65 & \\
\hline B & Building Component & & & \\
\hline 1 & Pepalihan & 38 & 62 & Doesen't \\
\hline 2 & Materials & 71 & 29 & have IMB : \\
\hline 3 & Balinese ornaments & 25 & 75 & \\
\hline $\mathrm{C}$ & Roofing Component & & & Responden \\
\hline 1 & Shape of roof & 83 & 17 & \\
\hline 2 & Materials of Roofing & 87 & 13 & \\
\hline 3 & Roof Ornament & 62 & 38 & \\
\hline $\mathrm{D}$ & Foot Component & & & \\
\hline 1 & Pondation & 71 & 29 & \\
\hline 2 & Elevation of building $+/-0.0$ & 69 & 31 & \\
\hline 3 & Materials & 51 & 49 & \\
\hline E & Facade & & & \\
\hline 1 & Gate Design & 87 & 13 & \\
\hline 2 & Free of Space & 37 & 63 & \\
\hline $\mathrm{F}$ & Percentage (in \%) & Percent & ge Comp & ence $(\operatorname{din} \%)$ \\
\hline & $N=$ Sum A $/ 14 \times 100$ & $790 / 14$ & $100=5$ & \\
\hline & with : & & & \\
\hline & $\mathrm{N}=$ Percentage (in \%) & & & \\
\hline & Sum A = Complience total & & & \\
\hline & $14=$ complience aspect & & & \\
\hline
\end{tabular}

The results of the calculations presented in table 4 show that people with high income classifications have a higher compliance value with a compliance percentage of $61.8 \%$, while people with middle income have a compliance value with a compliance percentage of $28.3 \%$ while people with low income only reach $18,8 \%$. Based on field data, this is strongly influenced by the area of land that is the location for residential buildings, most of the respondents expressed objections if there should be a distance on each side of the building for various reasons, especially the reason for the efficiency of the land to be built.

Next, based on the field findings presented in table 10, people with high income have the highest level of compliance, which is $58.8 \%$, but this percentage has very low compliance points in the Balinese ornament section, out of 30 high-income community respondents, only 3 respondents who fulfilled the compliance requirements of the Balinese ornament. This is largely due to advances in information technology which make most people with high incomes reluctant to use Balinese ornaments in their residential buildings and prefer more modern ornamental ornaments.

Next, the data in table 4 shows the percentage of compliance with a high ratio, low-income people (58.8\%), middle-income people $(84.1 \%)$ and high-income people $(86.6 \%)$. respondents still maintain the form of the roof in the form of a limasan and a minimum of a saddle, and use roofing materials in the form of tiles and / or those that resemble tiles, and still use roof ornaments in the form of pemugbug and join celedu as in traditional Balinese buildings. 
In the building appearance component section, respondents with middle income have a percentage level of compliance $(73.7 \%)$, people with high income $(51.6 \%)$ and people with low income $(56.6 \%)$. In the findings of this field, middle-income people have the highest level of compliance because some of the respondents have a trowel and have a building fence in accordance with the rules, which has a shape / pattern / motif and is not taller than 150 $\mathrm{cm}$. The absence of sufficient boundaries is also a benchmark for assessing field findings. Only middle-income respondents exceeded the $50 \%$ compliance rate.

\section{Individual Community Preferences (Analytic Hierarchy Process)}

This analysis is used to find a general order that is prioritized in complying with Mayor Regulation No. 25/2010. Each community group in South Denpasar has different views in choosing. Table 23 shows the differences in people's preferences in complying with Mayor Regulation Number 25 of 2010 from the aspect of value.

TABLE VI

COMMunity INDIVIDUAL PREFERENCES IN COMPLYING WITH PERWALI No. 25/2010 (VALUE ASPECTS)

\begin{tabular}{|c|c|c|c|c|c|c|}
\hline \multirow{3}{*}{$\begin{array}{l}\text { No } \\
1\end{array}$} & \multicolumn{6}{|c|}{ Community Preference \% } \\
\hline & \multicolumn{2}{|c|}{ Low Income } & \multicolumn{2}{|c|}{ Mid income } & \multicolumn{2}{|c|}{ Hight Income } \\
\hline & Economic & $\begin{array}{l}53 \\
6 \%\end{array}$ & Economic & $\begin{array}{l}17,8 \\
\%\end{array}$ & $\begin{array}{l}\text { Economi } \\
\text { c }\end{array}$ & $5,7 \%$ \\
\hline 2 & Security & $\begin{array}{l}21 \\
9 \%\end{array}$ & Security & $\begin{array}{l}23,5 \\
\%\end{array}$ & Security & $\begin{array}{l}57,9 \\
\%\end{array}$ \\
\hline 3 & $\begin{array}{l}\text { Architectur } \\
\text { e } \\
\text { Traditional } \\
\text { Bali }\end{array}$ & $\begin{array}{l}11 \\
9 \%\end{array}$ & $\begin{array}{l}\text { Architecture } \\
\text { Traditional } \\
\text { Bali }\end{array}$ & $\begin{array}{l}43,8 \\
\%\end{array}$ & $\begin{array}{l}\text { Architect } \\
\text { ure } \\
\text { Tradition } \\
\text { al Bali }\end{array}$ & $\begin{array}{l}11,9 \\
\%\end{array}$ \\
\hline 4 & $\begin{array}{l}\text { Complienc } \\
\text { e Efect }\end{array}$ & $\begin{array}{l}7,9 \\
\%\end{array}$ & $\begin{array}{l}\text { Complience } \\
\text { Efect }\end{array}$ & $8,5 \%$ & $\begin{array}{l}\text { Complien } \\
\text { ce Efect }\end{array}$ & $\begin{array}{l}19,8 \\
\%\end{array}$ \\
\hline 5 & $\begin{array}{l}\text { Social } \\
\text { Aspect }\end{array}$ & $\begin{array}{l}4,7 \\
\%\end{array}$ & Social Aspect & $6,3 \%$ & $\begin{array}{l}\text { Social } \\
\text { Aspect }\end{array}$ & $4,7 \%$ \\
\hline & Total & $\begin{array}{l}100 \\
\%\end{array}$ & Total & $\begin{array}{l}100 \\
\%\end{array}$ & Total & $\begin{array}{l}100 \\
\%\end{array}$ \\
\hline
\end{tabular}

The preferences of low-income people in complying with Mayor Regulation Number 25 of 2010 are based on the Analytic Hierarchy Process, from the order of priority being the economic value $(53.6 \%)$, the value of safety and comfort $(21.9 \%)$, the value of maintaining traditional architecture $(11,9 \%)$, the value of obedience to the rules (7.9\%), and the value of social recognition $(4.7 \%)$.

The preferences of middle-income people in complying with Mayor Regulation Number 25 of 2010 based on the Analytic Hierarchy Process of the order of priority are the value of maintaining traditional architecture (43.8\%), the value of security and comfort $(23.5 \%)$, economic value (17, $8 \%$ ), the value of obedience to the rules $(8.5 \%)$, and the value of social recognition $(6.3 \%)$.

The preferences of middle-income people in complying with Mayor Regulation Number 25 of 2010 are based on the Analytic Hierarchy Process, the order of which is the most prioritized is the value of safety and comfort (57.9\%), the value of obedience to rules $(19.8 \%)$, maintaining traditional architecture $(11,9 \%)$, economic value $(5.7 \%)$, and social recognition value $(4.7 \%)$.

The results of the analysis obtained by the researcher according to Table 23 show that the highest priority value is in the aspect of the value of comfort with an average percentage $(34.43 \%)$ while the lowest priority is in the aspect of the value of social recognition with an average percentage $(5.23 \%)$. .

Next is the difference in people's preferences in complying with Mayor Regulation No. 25/2010 from the aspect of building components. The building components in question are building demarcation lines, building body components, building roof components, building leg components, and front view components.

TABLE VII

RELIABILITY TEST RESUlTS

\begin{tabular}{|c|c|c|c|c|c|c|}
\hline \multirow{3}{*}{$\begin{array}{l}\text { No } \\
1 \\
\end{array}$} & \multicolumn{6}{|c|}{ Community Preference \% } \\
\hline & \multicolumn{2}{|c|}{ Low Income } & \multicolumn{2}{|c|}{ Mid income } & \multicolumn{2}{|c|}{ Hight Income } \\
\hline & Frontier & 3,9 & Frontier Line & 22,5 & Frontier & 28,3 \\
\hline & Line & $\%$ & & $\%$ & Line & $\%$ \\
\hline \multirow[t]{3}{*}{2} & Body of & & Body of the & 40,1 & Body of & 21,9 \\
\hline & & & Building & $\%$ & the & $\%$ \\
\hline & Building & & & & Building & \\
\hline \multirow[t]{2}{*}{3} & Roofing & 51 & Roofing & 16,5 & Roofing & $9,2 \%$ \\
\hline & Component & $4 \%$ & Component & $\%$ & $\begin{array}{l}\text { Compone } \\
\text { nt }\end{array}$ & \\
\hline \multirow[t]{2}{*}{4} & Footing & 25 & Footing & $7,8 \%$ & Footing & 17,7 \\
\hline & Component & $4 \%$ & Component & & $\begin{array}{l}\text { Compone } \\
\text { nt }\end{array}$ & $\%$ \\
\hline \multirow[t]{4}{*}{5} & Facade & 14 & Facade & 13,1 & Facade & 22,8 \\
\hline & & $3 \%$ & & $\%$ & & $\%$ \\
\hline & Total & 100 & Total & 100 & Total & 100 \\
\hline & & $\%$ & & $\%$ & & $\%$ \\
\hline
\end{tabular}

The preferences of low-income people in complying with Mayor Regulation Number 25 of 2010 are based on the Analytic Hierarchy Process, the order of which is the most prioritized is the building body component (51.4\%), the roof component $(25.4 \%)$, the building leg component $(14.3$ $\%)$, the front view component $(5.0 \%)$, and the building border line $(3.9 \%)$.

The preferences of middle-income people in complying with Mayor Regulation Number 25 of 2010 are based on the Analytic Hierarchy Process, the most prioritized order is building body components $(40.1 \%)$, building demarcation lines $(22.5 \%)$, building roof components (16.5\%), front view components $(13.1 \%)$, and building foot components $(7.8 \%)$.

The preferences of middle-income people in complying with Mayor Regulation Number 25 of 2010 are based on the Analytic Hierarchy Process, the order of which is the most prioritized is the building demarcation line (28.3\%), the front view component $(22.8 \%)$, the building body component $(21.9 \%)$, the building leg component $(17.7 \%)$ and the roof component $(9.2 \%)$.

The results of the analysis obtained by the researcher according to Table 24 show that the highest priority value is in the aspect of the building body component with an 
average percentage $(37.80 \%)$ while the lowest priority is in the aspect of the building leg component with an average percentage $(13.26 \%)$.

\section{CONCLUSION}

The determinants of people's preferences in complying with Mayor Regulation No. 25/2010 in South Denpasar vary widely, because each group of people has different levels of compliance and desire. The results of this study indicate that there are differences in preferences that are important in terms of the economic capacity of the community as respondents.

Low-income people have a level of compliance with Mayor Regulation Number 25 of 2010 (28.82\%) and have a preference in the form of an attitude scale with a very important choice (SP) on the economic value aspect of residential buildings, and consider all determinant factors in the form of value and value aspects. aspects of building components at a very insignificant position (Newrank data). Next, low-income people prioritize the choice of choosing aspects of economic value rather than having to spend funds to meet the requirements of other value aspects (AHP data). Low-income people also have a preference in the form of prioritizing their choice of building body components compared to other aspects of building components $(51.4 \%)$ and consider that the building demarcation line $(3.9 \%)$ is the least prioritized thing.

Middle-income people have a level of compliance with Mayor Regulation Number 25 of 2010 (63.36\%) and have a preference in the form of an attitude scale with choices on value aspects and aspects of building components in ordinary, important, and very important (BP-SP) positions of society. middle-income earners do not consider one determinant to be insignificant or even very insignificant (Newrank data). Next, middle-income people prioritize the choice of choosing the value aspect of maintaining traditional architecture (AHP data). Middle-income people also have a preference in the form of prioritizing their choice of building body components compared to other aspects of building components $(40.1 \%)$ and perceiving that the leg components $(7.8 \%)$ are the least prioritized.

High-income people have a level of compliance with Mayor Regulation Number 25 of 2010 (69.34\%) and have a preference in the form of an attitude scale with choices on value aspects and aspects of building components in ordinary, important, and very important positions (BP-SP) with the exception of on the aspects of economic value and value aspects maintaining Balinese architecture (STP). (Newrank data). Next, high-income people prioritize the choice of choosing aspects of safety and comfort values (AHP data). High-income people also have a preference in the form of prioritizing their choice of building boundary components compared to other aspects of building components $(28.3 \%)$ and consider that the roof component of the building $(9.2 \%)$ is the least prioritized.
From the conclusion of the research data above, it can be stated that people with higher income have a higher level of compliance than others, but do not have a good attitude scale towards compliance with applicable regulations, and vice versa, low-income people have a good attitude scale. in complying with Mayor Regulation Number 25 of 2010 but inversely proportional to the level of compliance.

\section{REFERENCES}

[1] Alabede, J. O. 2011. Tax Service Quality and Compliance Behaviour in Nigeria: Do Taxpayer's Financial Condition and Risk Preference Play any Moderating Role? European Journal of Economics, Finance and Administrative Sciences , 90 - 107. ISSN 1450-2275 Issue 35

[2] Aparwati, E. 1998. Aspek-aspek Sosial Psikologis pada Pemukiman Masyarakat Berpendapatan Rendah di Kota-Kota Besar. Bandung: PT.Alumni.

[3] Bierstedt, Robert. 1970. The Social Order. Tokyo: McGraw-Hill Kogakusha, Ltd.

[4] Budiharjo, E. 1997. Sejumlah Permasalahan Permukiman Kota. Bandung: PT. Alumni.

[5] ----------. 1998. Sejumlah Masalah Permukiman Kota. Bandung: PT. Alumni.

[6] ----------. 2009. Perumahan dan Permukiman di Indonesia. Bandung: PT. Alumni.

[7] Ching, Francis D.K. 1979. Arsitektur: Bentuk - Ruang dan Susunannya, Penerbit Erlangga.

[8] Departemen Pendidikan Nasional, 2001. Kamus Besar Bahasa Indonesia. Jakarta: Balai Pustaka.

[9] E. Utrecht. 1963. Pengantar Hukum Administrasi Negara Indonesia Cet VI. Jakarta: Balai Buku Ichtiar.

[10] Edmund N. Bacon,1974. Design Of Cities

[11] Halim, D. K. 2008. Psikologi Lingkungan Perkotaan. Jakarta: PT. Bumi Aksara.

[12] Heri, P. 1999. Pengantar Perilaku Manusia untuk Keperawatan. Jakarta: EGC.

[13] Nasir, M. 1999. Metodelogi Penelitian. Jakarta: Ghalia Indonesia.

[14] Niven, N. 1994. Health Psychology: An Introduction for Nurses and Other Health Care Professionals. Agung, W. 2002 (alih bahasa). Jakarta: EGC.

[15] Smet, B. 1994. Psikologi Kesehatan. Jakarta: Grasindo.

[16] Soekanto, Soerjono. 1982. Sosiologi Hukum dalam Masyarakat. Jakarta: Rajawali Pers.

[17] ------------. 1993. Faktor yang Mempengaruhi Penegakan Hukum. Jakarta: Rajawali Pers.

[18] Tim Penyusun Kamus Pusat Bahasa. 2002. Kamus Besar Bahasa Indonesia. Jakarta: Balai Pustaka.

[19] Torgler, B. 2003. Tax Morale and direct Democracy. Europan Journal Of Political Economy 